\title{
Diagnostic and prognostic usefulness of mid- regional pro-adrenomedullin levels in patients with severe sepsis
}

\author{
F Valenzuela Sanchez ${ }^{1 *}$, B Valenzuela Mendez ${ }^{2}$, R Bohollo de Austria', JF Rodríguez Gutierrez³, M Jaen Franco', \\ MA González García ${ }^{4}$, A Jareño Chaumel ${ }^{1}$
}

From ESICM LIVES 2015

Berlin, Germany. 3-7 October 2015

\section{Introduction}

Mid-regional pro-adrenomedullin (MR-proADM) is a fragment of 48 amino acids which splits from the final proADM molecule in a ratio of 1:1 with ADM. It is essentially irrelevant, but proportionally represents the levels and activity of ADM. Its half-life is several hours longer, and its plasma concentrations can be determined in clinical practice. It has been identified as a prognostic marker, stratifying the mortality risk in patients with sepsis.

\section{Objectives}

To evaluate the usefulness of MR-proadrenomedullin (MR-proADM) levels in the diagnosis and prognosis of sepsis in patients admitted to the ICU.

\section{Methods}

Prospective observational single-center study. A total of 120 consecutive patients with suspected severe sepsis were recruited to the ICU of Jerez Hospital. Epidemiological, clinical, laboratory data and MR-proADM, Procalcitonin (PCT), and C-reactive protein (CRP) levels were collected at the time of admission, at 48 hours, at the 5th day and on the day of discharge from the ICU.

\section{Results}

104 patients were diagnosed at discharge of severe sepsis and 16 patients were diagnosed of SIRS without sepsis. The group of septic patients reached MRproADM levels of $4.05 \mathrm{nmol} / \mathrm{l}$ vs of $0.309 \mathrm{nmol} / \mathrm{l}$ in not septic patients $(\mathrm{p}<0.0001)$. The AUC-ROC was 0.9474 (Figure 1).
At 48 hours after admission the MR-proADM levels in surviving septic patients fell to $1.65 \mathrm{nmol} / \mathrm{l}$ and in the non-survivors $2.475 \mathrm{nmol} / \mathrm{l}(\mathrm{p}=0.04)$. On the 5 th day following admission the survivor levels fell to $1.36 \mathrm{nmol} / \mathrm{l}$ vs $3.42 \mathrm{nmol} / \mathrm{l}$ in the septic patients who died in the ICU $(p=0.0006)$. At the 5 th day the survivors showed greater clearance MR-proADM with a median level of $62.7 \%$ vs $21.2 \%$ in the non-survivors (Table 1).

The AUC the ROC curve at the 5th day was: MRproADM 0,828( $\mathrm{p}=0,001)$; PCT $0.725(\mathrm{p}=0,016)$ CRP $0.700(p=0,0214)$. The AUC the ROC curve to MRproADM clearance at the 5 th day was $0,734(\mathrm{p}=$ 0,0104) (Figure 2)

Patients with MR-proADM levels of $2.5 \mathrm{nmol} / \mathrm{l}$ and above or MR-proADM clearance less than $30 \%$ at the 5 th day following admission in the ICU showed an enhance in mortality $(\mathrm{p}<0.0001)$. In the multivariate analysis (Cox proportional hazards models) MRproADM levels and MR-proADM clearance at the 5th day following admission, were statistically significant predictive factors for mortality in the ICU and at 90 days (Figure 3).

\section{Conclusions}

Initial MR-proADM levels help to identify the infectious origin in patients with SIRS and organ dysfunction. MRproADM levels and its clearance at the 5th day following admission are the most effective biomarker to determine unfavorable evolution and the risk of mortality in patients with severe sepsis admitted to the ICU. 


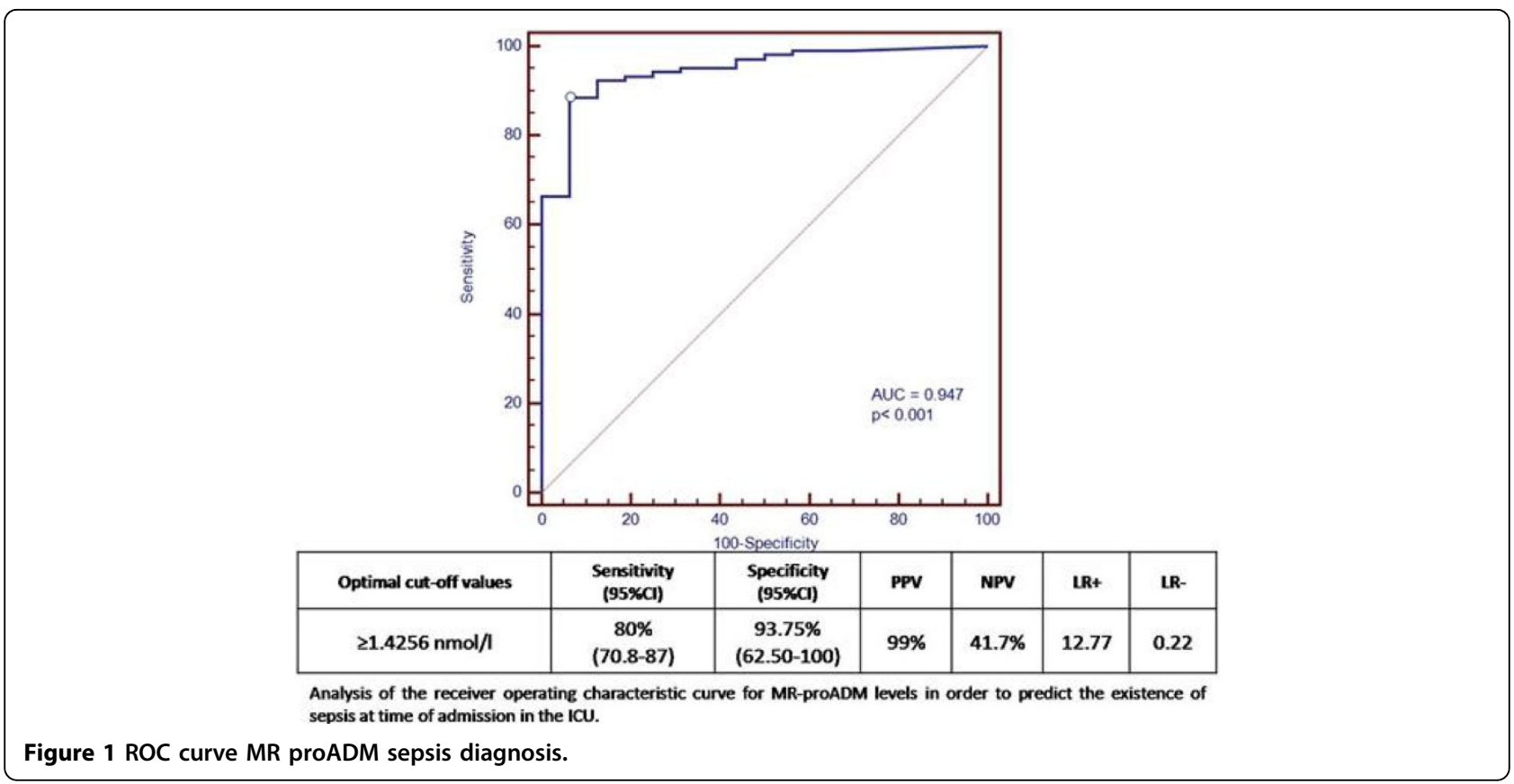

Table 1 MR-ADM levels and clearance in survival subgroups

\begin{tabular}{|c|c|c|c|c|c|}
\hline & SEPTIC SURVIVORS & SEPTIC SURVIVORS & SEPTIC NON SURVIVORS & SEPTIC NON SURVIVORS & \\
\hline MR-proADM & median & IQR & median & IQR & $p$ \\
\hline ADMISSION levels (nmol/I & 3.04 & $1.67-6.8$ & 5.7 & $1.81-7.79$ & $p=0.263$ \\
\hline 48 HOURS levels $(\mathrm{nmol} / \mathrm{l}$ & 1.65 & $1.11-3.62$ & 2.47 & $1.43-6.48$ & $p=0.04$ \\
\hline 5TH DAY levels (nmol/l & 1.36 & $0.88-1.96$ & 3.42 & $2.18-10.57$ & $p=0.0006$ \\
\hline DISCHARGE levels (nmol/l) & 1.268 & $0.88-1.78$ & & & \\
\hline 48 HOURS Clearance (\%) & 43.2 & $14.4-60.5$ & 22.8 & $-1.3-59.72$ & $p=0.20$ \\
\hline 5TH DAY Clearance (\%) & 62.7 & $46.17-82.3$ & 21.2 & $-38.7-61$ & $p=0.015$ \\
\hline
\end{tabular}

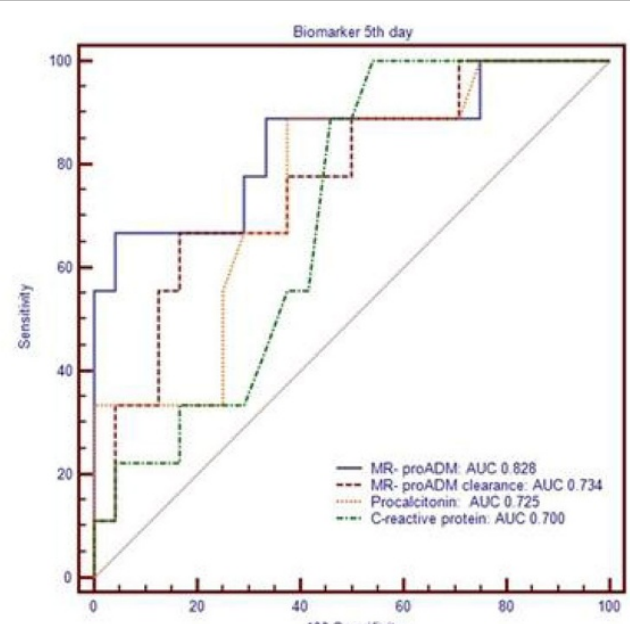

\begin{tabular}{|c|c|c|c|c|c|c|c|}
\hline & $\begin{array}{l}\text { Optimal } \\
\text { cutoff values }\end{array}$ & $\begin{array}{c}\text { Sensitivity } \\
\text { (95\%c) }\end{array}$ & $\begin{array}{l}\text { Specificity } \\
\text { (95\%व) }\end{array}$ & $\begin{array}{c}\text { PPV } \\
(95 \% \text { a) }\end{array}$ & $\begin{array}{c}\text { NPV } \\
\text { (95\%C) }\end{array}$ & $\begin{array}{c}\text { LRt } \\
\text { (95\%a) }\end{array}$ & $\begin{array}{c}\text { LR- } \\
\text { (95\%()) }\end{array}$ \\
\hline $\begin{array}{l}\text { MR-proADM } \\
\text { T5"' DAY }\end{array}$ & $>2.529$ & $\begin{array}{c}77 \% \\
46.2-95.0\end{array}$ & $\begin{array}{c}97 \% \\
84.7-99.9\end{array}$ & $\begin{array}{c}91 \% \\
58.7-99.8\end{array}$ & $\begin{array}{c}92 \% \\
77.3-98.3\end{array}$ & $\begin{array}{c}26.15 \\
3.7-184.5\end{array}$ & $\begin{array}{c}0.24 \\
0.09-0.6\end{array}$ \\
\hline
\end{tabular}

Analysis of receiver operating characteristic curves, at the $5^{\text {th }}$ day following admission in the Intensive Care Unit for septic patients in order to predict mortality

Figure 2 ROC curves Biomarker 5th day prognosis. 


\begin{tabular}{|c|c|c|c|c|c|}
\hline & \multicolumn{5}{|c|}{ Endpoint: 90-DAY MORTALITY } \\
\hline & Variable & $\begin{array}{l}\text { Hazard Ratio } \\
\text { (95\%व) }\end{array}$ & $\begin{array}{l}\text { Regression } \\
\text { Coefficient }\end{array}$ & Standard error & p value \\
\hline AT ADMMISSION & Apache II & $\begin{array}{c}1.1231 \\
1.077-1.170\end{array}$ & 0.1161 & 0.02119 & $<0.0001$ \\
\hline \multirow{2}{*}{ AT 48 HOURS } & Apache II & $\begin{array}{c}1.0983 \\
1.039-1.160\end{array}$ & 0.09379 & 0.02812 & 0.0009 \\
\hline & $\begin{array}{l}\text { MR-proADM } 48 \\
\text { hours }\end{array}$ & $\begin{array}{c}1.0756 \\
1.008-1.147\end{array}$ & 0.7290 & 0.03331 & 0.0286 \\
\hline \multirow{4}{*}{ AT $5^{\text {th }}$ DAY } & Age & $\begin{array}{c}1.0557 \\
1.056-1.108\end{array}$ & 0.05425 & 0.02495 & 0.0297 \\
\hline & Immunodeficiency & $\begin{array}{c}4.2387 \\
1.257-14.29\end{array}$ & 1.4443 & 0.6233 & 0.0205 \\
\hline & MR-proADM $5^{\text {th }}$ day & $\begin{array}{c}1.2199 \\
1.102-1.350\end{array}$ & 0.1988 & 0.05204 & 0.0001 \\
\hline & $\begin{array}{c}\text { MR-proADM } \\
\text { clearance } 5^{\text {th }} \text { day }\end{array}$ & $\begin{array}{c}0.9959 \\
0.993-0.998\end{array}$ & -0.004091 & 0.004091 & 0.0046 \\
\hline
\end{tabular}

Figure 3 multivariate analysis mortality 90 days.

\section{Authors' details}

'Hospital del SAS de Jerez, Critical Care Medicine, Jerez de la Frontera, Spain. ${ }^{2}$ Hospital Universitari Germans Trias i Pujol, Obstetric and Ginecology

Department, Barcelona, Spain. ${ }^{3}$ Hospital del SAS de Jerez, Hematology, Jerez de la Frontera, Spain. ${ }^{4}$ Hospital del SAS de Jerez, Clinical Analysis Laboratory, Jerez de la Frontera, Spain.

Published: 1 October 2015

\section{Submit your manuscript to a SpringerOpen ${ }^{\mathcal{O}}$ journal and benefit from:}

- Convenient online submission

- Rigorous peer review

- Immediate publication on acceptance

- Open access: articles freely available online

- High visibility within the field

- Retaining the copyright to your article 